\title{
THE TASIKMALAYA CHAOS IN 1996: BETWEEN THE SOCIETY'S SOLIDARITY AND THE SOCIO-ECONOMY IMBALANCE
}

\begin{abstract}
Sriyanto ${ }^{1}$
ABSTRACT

The harmony of Tasikmalaya society with its calm, polite, and peaceful life was in question when it was instantly turned agresive and violent. The 1996 Tasikmalaya Riot was a typology of collective behaviour which led the discourse into the Ethnic, Religion, and Race (SARA - Suku, Agama, Ras) problems by targetting their agresivity to churches and Chinese's stores. However, was the riot really the problem of the Ethnic, Religion, and Race, or was there another problem behind the peaceful life of Tasikmalaya people? This study attempts to find the answer to this question, through interview and documentation, to obtain primary sources. The social condition of Tasikmalaya people is agrarian with its strong Islamic boarding school culture. The base to analyse the Tasikmalaya riot is the theories of Islamic boarding school network and collective behaviour. The trigger of the riot was the torturing of ustadz, the Islamic preachers, by the police. This incident emerge the Moslem solidarity in Tasikmalaya which caused the riot at 26 December 1996. The riot's causes can be traced in the social-economy condition, the society culture, and Tasikmalaya society structure for a comphensive description. The collective behaviour of the Tasikmalaya riot in 1996 is a representative of social, economy, and law imbalance. The riot was an important learning process for the people and officers in Tasikmalaya.
\end{abstract}

Key words: Tasikmalaya, chaos, Islamic boarding school culture

${ }^{1}$ Sriyanto, lecturer of Muhammadiyah University of Purwokerto. For academic interest, the author can be contacted through the office address: Jl Dukuhwaluh No. 1, Purwokerto, Central Java. 


\section{Introduction}

The socio-political situation before the the collapse of the New Order regime and the beginning of the reformation period is characterized by the phenomenon of riots in various regions in Indonesia. The riot can be grouped in the form of inter-ethnic tension, riots caused by religious issues, and conflict between groups. The mass riot in Situbondo (October 1996), Tasikmalaya (December 1996), Rengasdengklok (January 1997), Banyuwangi (September 1998), Ketapang (November 1998), Kupang (December 1998), Ambon and Sambas (since March 1999) had a wide effect to the social relationship in Indonesia. The riots suggests that political order built firmly during the New Order era and its restricted conflict of social life which was in fact disintegrating with a loss of trust among the parties in conflict, the relationships which were built for the harmony of the society and the state were broken, and the compliance to the norms regulation and social order that had been agreed together was lost.

The social conflict which was more intense, spread wider, unavoidably raised the contradictory questions with the reality of Indonesia. These questions are of course understandable, because according to the Indonesian history, Indonesia has been indentified as a friendly and tolerance nation (Darmawan, 2006), but after the collapse of New Order era Indonesia showed the character of repression, expressed by degree of the unhuman violence, which was unbelievable.

The Tasikmalaya Riot, happened on Thursday, on December 26, 1996, had shocked various parties because it was contradictory with the culture of Tasikmalaya. The characteristic of Sundanese people, which is the majority of Tasikmalayan, is to always put tolerance and togetherness. Politeness is the custom that firmly holds by the people. These characteristics are supported by its religious society, therefore the Tasikmalaya people are known as the religious people. However, despite the fact of that religious society, there were latent conflict which led to the riots. Like the fire in the chaff, there is fire in the peace that could flare up any time. Based on these assumptions, to understand the Tasikmalaya riot required a comprehensive understanding to see the secrets behind the politeness and civility of Tasikmalaya citizen. The issue of economic, social, and political developments at the national level can be an analytic tool to explore the Tasikmalaya Riot.

Observing the riots in Indonesia, including in Tasikmalaya, before the fall of the New Order regime, from both political and economic perspectives was in contrast to the strong position of the country at that time, when economic growth was also quite high. From the point of view of sociology and culture, the paradox was more apparent with the characteristics of the Indonesian people who prefer the collectivity and togetherness rather than individual interests (Maftooh, 2008: 6). Collectivist societies tend to prioritizing group consensus reflected in the desire to create harmony. Javanese and Sundanese culture for example, is generally a culture that which prioritize harmony and togetherness. A society that values togetherness tends to avoid conflict. It should be noticed that the riots in Tasikmalaya, in a peaceful, tolerant and religious society, and the ethnic and religious issues aroused in the incident. 
The Tasikmalaya riot in 1996 was a typology of collective behavior to carry out destructive acts against public facilities and the facilities belong to different ethnic groups and religions. The incident triggered the riot was actually had nothing to do with social issues, but extends to the issue of discrimination against Chinese. That incident in Tasikmalaya was not the first incident, had occured a series of riots which brought up religious and ethnic issues in Indonesia such as in 1918 in Kudus, 1963 in Cirebon and Sukabumi, 1963 and 1973 in Bandung (Sjamsuddin, 2002), in Purwakarta, West Java in 1995, 1997 in Ujung Pandang, Medan in 1998, and in 1998 in Jakarta and Solo (Sholeh et.al., tt.).

Meanwhile, according to the data from Media Transparansi which record the social riot during the end of New Order regime and while approaching the generel election of 1997 (1995-1997) are as follows:

The Riots During the New Order Era 1995-1997

\begin{tabular}{|c|c|}
\hline Date & Event \\
\hline $\begin{array}{l}\text { 31st Oct -2nd } \\
\text { Nov } 1995\end{array}$ & $\begin{array}{l}\text { The moslem society of } \\
\text { Purwakarta was angry } \\
\text { and destroying stores, } \\
\text { due to a Tsanawiyah } \\
\text { student was punished } \\
\text { to mop the floor using } \\
\text { her vail because she was } \\
\text { stealing. }\end{array}$ \\
\hline $\begin{array}{l}\text { 24th November } \\
1995\end{array}$ & $\begin{array}{l}\text { Hundreds moslems } \\
\text { destroyed dozens of } \\
\text { non-indigenous stores } \\
\text { Muslims reacted to a } \\
\text { non-moslem tore the } \\
\text { Quran. }\end{array}$ \\
\hline
\end{tabular}

\begin{tabular}{|c|c|}
\hline $\begin{array}{l}\text { 12th March } \\
1996\end{array}$ & $\begin{array}{l}\text { The people around } \\
\text { Timika attacked the } \\
\text { gold mining company } \\
\text { due to the rumor that } \\
\text { a local citizen got hit by } \\
\text { Freeport's employee. }\end{array}$ \\
\hline 27th July 1996 & $\begin{array}{l}\text { Jakarta was in riot and } \\
\text { dozens building was on } \\
\text { fire due to the seizure } \\
\text { of DPP PDI office by } \\
\text { Soerjadi (the Chairman } \\
\text { of PDI of Medan congress } \\
\text { Version) who againts } \\
\text { Megawati }\end{array}$ \\
\hline $\begin{array}{ll}10 t h & \text { October } \\
1996 & \end{array}$ & $\begin{array}{l}\text { The people of Situbondo- } \\
\text { Jawa Timur run amok } \\
\text { because they were } \\
\text { unsatisfied with the } \\
\text { chargetowardtheaccused } \\
\text { Kyai as insulter. } 24 \\
\text { churches, court, several } \\
\text { shcools and orphanage } \\
\text { were destroyed. }\end{array}$ \\
\hline $\begin{array}{l}\text { 26th December } \\
1996\end{array}$ & $\begin{array}{l}\text { Tasikmal aya-Jawa } \\
\text { Barat was in riot. } 83 \\
\text { stores, dozens cars, } 4 \\
\text { factories, } 4 \text { churches was } \\
\text { destroyed and burnt. }\end{array}$ \\
\hline $\begin{array}{l}\text { 3othDecember } \\
1996 \text { - 2nd } \\
\text { January } 1997\end{array}$ & $\begin{array}{l}\text { The people of Ledo } \\
\text { Sub-district attacked } \\
\text { the Sangau Ledo } \\
\text { Sub-district, Sambas, } \\
\text { Kalimantan Barat. } \\
\text { Several houses were } \\
\text { burnt and alot of people } \\
\text { had been the victim. }\end{array}$ \\
\hline
\end{tabular}




\begin{tabular}{|l|l|}
\hline 28th January & $\begin{array}{l}\text { The street vendors } \\
\text { of Tanah Abang-Jakarta } \\
\text { Pusat burnt the Sub- } \\
\text { district office and cars, } \\
\text { because there was a } \\
\text { vendor who was hit by } \\
\text { the Tramtib car. }\end{array}$ \\
\hline
\end{tabular}

Source: Media Transparansi 9/Juni 1999 issue

The tendency of violence committed by the society was probably a representation mode of the results of social reproduction through a process of internalization of cognitive experience, after the violence in the previous period was dominated by the stateviolenceand committed systematically through institutionalized institutions. The economic growth-prioritized government policies had neglected the cultural growth, therefore the economic progress was not accompanied by a steady cultural foundations. The economic growthoriented goverment policy was not spread evenly in all area of Indonesia, therefore, the anti-minority attitude was very common, such as anti-Chinese. Some antiChinese incident happened at the end of the New Orderera.

The cause of the riot in Tasikmalaya can be traced from the incidents of torture and outrages committed by police officers against the management people of a pesantren, the Islamic boarding school. The incident caused a pesantren figure got injured and must be hospitalized. The riot that erupted on Thursday, December 26, 1996, seems to have put a red note in the history of Tasikmalaya people, who had a calm and stable life. The incident resulted in a considerable depth of trauma and had killed five people, at least 100 buildings such as shops, factories, banks, churches, police stations and schools were destroyed or scorched. The riot also resulted in the destruction of the citizen's houses and tense conditions which disrupted the people's activities.

Observing some of the riots that have occurred in the area shows that mass was immediately committed out of control destructive acts, which is not in accordance with the norms shared by most people of Indonesia. If the riot and the conflict happened was caused by the diveristy, in fact the Indonesian people have lived for centuries in diversity, in fact diversity is the characteristic of Indonesian. Therefore the notion of entanglement of local identities that unite Indonesia is an important part of the history of how this country was created. This fact raises questions about the situation in Indonesia, what exactly is the root of conflicts which led to the riot during that period?

Scott (1993), a social theorist, explained that behind the calm of the agrarian society there is conflict inside it. Scott's studies on the Sadakan society, may explain these allegations with the movement he called "everyday of resistance." Likewise, the collective action analysis of Tilly (Skocpol, 1991, 8-9) exposes two models of political and community mobilizations. The analysis of Smelser explains that essentially the social movements did not occur in a sudden, but through a rational stages (Adib, 2008). The Tasikmalaya riots carried out by the masses in the form of collectivism (togetherness), the mass psychology of behavior associated with a group called the mass of collective behavior. Scott's and Smelser's analysis of the mass movement had drawn the attention to understand why the religious people of Tasikmalaya had acted destructively toward public facilities? And whether the collective behavior that caused casualties and material 
losses on the Chinese people was merely a spontanous act?

Based on the chronology, the mass' aggresivity occured in Tasikmalaya was toward two matters, the first was toward the Tionghoa ethnic group and the public facilities such as churches, Christian/ Catholic schools, while the second target was the police station. The aggresivity aimed at the destruction of the police station can be understood as a form of solidarity of Tasikmalaya as reacted to the police officers act towards an ajengan (ustadsthe Islamic priest), as the role model of the society and students. Meanwhile, the target toward attack to the Chinese community and the church has no direct connection with the incident trigered the riot, which lead to the question thats is there any social relationship between Tasikmalaya people and the Chinese community, as depicted in Tasikmalaya society dynamics? Every event in the historical perspective should be understood comprehensively, it means that every event is not only seen in the context of the event, but there are factors that surround and accompany the why and how it happened. Likewise with the riot in Tasikmalaya, to find the reason why the incidents of the Pesantren can escalate into a great riot requires studies on the economic, social, political, and cultural of Tasikmalaya society.

\section{Study Focus}

Historically, the development of horizontal conflict caused by the religious and ethnic issues in Indonesia does not actually have historical roots. However, the emergence of religion and ethnicity issues in riots happened in Indonesia has raised several problems. The problem of the riot in Tasikmalaya could be identified by explaining the causes, the incident process and its impact, an the conflict resolution of the event. Therefore, the questions for this study are as follows:

1. What was the social situation of Tasikmalaya before the riot in 1996?

2. What was the cause of the riot in Tasikmalaya in 1996?

3. What was the chronology of the riot in Tasikmalaya in December 1996?

4. What was the conflict resolution of the riot in Tasikmalaya in 1996?

\section{Study objectives}

The main objetive of this study is to find out the the answer of the questions with an historical approach in a descriptivequalitative based on the available resources, primary and secondary, which the problems formulation are as follows:

1. to know the social situation of Tasikmalayasocietybefore 1996inorder to get the descriptions in explaining the riot happened in Tasikmalaya.

2. to know the reasons of the riot in Tasikmalaya in 1996 as the horizontal conflict case in the frame of the New Order constellation, and the socialeconomy situation in Tasikmalata during that time.

3. to describe the riots in the critical-logical and chronological historical perspective in the frame of religious and ethnic issues which involved the indigenous and nonindigenous (Chinese ethnic) as the target of the riots

4. to explain the steps, methods, and practices adopted in the conflict resolution of the Tasikmalaya riot in 1996 as a peace-building effort to 
live side by side in harmony between groups, ethnic, and religion.

\section{Theoretical Foundation}

Smelser (1962), in his Theory of Collective Behavior reveals that there are four basic components of collective behavior: (1) generalized ends purposes or the values which provides a wide direction on the purposive social behavior, (2) regulatory provisions governing efforts to achieve these objectives, including the rules contained in the norms, (3) individual energy mobilization to achieve objectives that have been formulated in the normative framework. If the actor is regarded as an individual, then find out how he was motivated; and in the levels of the social system, find out how these motivated individuals are organized in the roles and organization, (4) the availability of situational facilities, where the actors use it as a means. The facilities are include the knowledge about the environment, the estimation consequences of actions, tools and skills.

Furthermore Smelser identifies six stages of a condition that allows the emergence of collective behavior (Mustain, 2007: 187-188; Suryanto, 2008), namely: (a) structural conduciveness, that some social structures that allow the emergence of collective behavior, such as: markets, public places, places of worship, shopping malls, etc., (b) structural strain, the emergence of tension in society that emerged in a structuraly, (c) generalized beliefs: shared interpretation of events, the development of a hatred prejudice toward something, such as government, racial groups, religion, or political opponents; (d) precipitating factors: there is a triggering incidence; (e) mobilization for actions: the mobilization of the masses, and (f) failure of social control - due to the agents assigned to conduct the social control do not do it properly.

\section{Study method}

The sources of data obtained through in-depth interviews. Moreover, data were also obtained from the written resources such as books, journals, research and other publications. The sources for qualitative research are selected and prioritizing the emic perspective (the insider point of view), how they perceive and interpret the world from the informant point of view (Moleong, 2007; Berg, 2007). In accordance with the focus of the research, the sources of the data are the kyai (Islamic shcolars), students, officials and government offices, community leaders, and citizens of Tasikmalaya. The data analysis is inductive, an analysis based on the data obtained. Sugiyono (2007: 91) suggests that activity in qualitative data analysis is done interactively and continues over time until it completes. At the time of the interview, the researcher has conducted an analysis of the interviewees answer, and if the answers are not satisfactory then the researchers asked further questions, until data deemed credible are achieved. The steps in conducting data analysis are data reduction, the data display, and conclusion drawing / verification (Miles \& Huberman, 1992: 20).

\section{Study Result and Discussion}

\section{Tasikmalaya society's structure}

The social structure in this study refers to Ekadjati opinion (1995: 198) about the relationships occured among individuals 
or groups of individuals in the community that have been patterned, so that it becomes a system of relations. Islam has a great influence in public life and have implications for the onset of Tasikmalaya social structure based on religion. The social status can be determined by the level of the science of religion mastery, obedience in conducting the religious rules, and activities in the field of religion. The higher the mastery of the religious knowledge, the more obidience the people in implementing the religion's rules, and more active in religious activities the higher the social status of a people. In connection to this, the Islamic scholar, Ajengan, and Ustadz occupy a high social status in the village community, followed by the students of islamic boarding school and the common people. In general, in the social life, the islamic scholars, Ajengan, ustadz, and Hajj could be classified as the religious figures, and respectable considered, as the elites (Ekadjati, 1995: 232).

The Tasikmalaya people (Sundanese) are also influenced by Javanese culture, from the era of Mataram, the feudalistic. This influence can be seen, for example, in the division of the Sundanese social groups, there are the menak (regent-upper class), or sentana dalem (the aristrocates, decendants of regent) and somah (common people) (Iskandar, 2001: 34-35). The other influence of Mataram is also reflected in the philosophy of Sunda guru, ratu, wong atua karo (Iskandar, 2001: 38). According to Ajip Rosidi, this philosopy transplanted from the Java, and it was adopted and taught until about the middle of the 2oth century. The meaning of the philosophy picturized the levels of people should be respected by everyone. The first is the "guru" (teacher), followed by "ratu" (queen), and the last are our parents. The teacher in the caste structure, aligned with the Brahmin, while the queen are the Warrior. Ajip Rosidi explained that the definition of teacher in the Sundanese philosophy is the people who should digugu (be trusted) and ditiru (imitated), that is, those whose behavior should serve as an example and role model of others (Rosidi, 1980: 118). Referring to this understanding of teacher (guru), the religious scholars, preachers, religious leaders, and the pesantren teachers are included in this category.

In the community which has a very strong religious nuance, such as Tasikmalaya, the role of religious leaders is very important in people's lives. Therefore, in Tasikmalaya ustadz have a respected social status by the society. The religious community life is based on a sacred matter, so that the social order is considered to have a close relationship with the powers above, that is God. Therefore the people have depended on religious leaders as their a life guardiance. Kyai is a sub-group of people who play an important role in Tasikmalaya. Kyai is one of the most respected people in the comunity's social life.

\section{The social-economy condition}

The economic system of Tasikmalaya regency is mostly agrarian economic system, the agriculture sector absorbed $41.13 \%$ of the Tasikmalaya workforce, followed by the industrial and trade sectors. The agricultural sectors are in almost all the districts of Tasikmalaya (except Cipedes, Cihideung, and Tawang), and predominant to the formation of GDP (Gross Domestic Product), that is equal to $32.38 \%$ compared to other sectors. In addition to agriculture, Tasikmalaya regency is also famous for its handicraft industry such as the 
Mendong mat and apparel (Cibeureum), woven bamboo and ijuk or fibers broom (Singaparna), embroidery (Kawalu), umbrella (Indihiang), woven straw hats and various other handicrafts (Rajapolah) (BPS, 1993: 37). While the potential trade sector of Tasikmalaya district is in the District of Cihideung which has reached $26.02 \%$, because in this area there are centers of business/ commercial, shopping, supermarkets, wholesalers and the largest market of Tasikmalaya.

Tasikmalaya district has been known for its home industry: the paper umbrella handicraft, embroidery, ladies slippers called kelom geulis, batik, sarong weaving, and various woven goods. This small industries existance make Tasikmalaya recognized as the center of economic growth in East Priangan egion. According to the Head of the Department of Small Industry and Handicraft Industry of Tasikmalaya, Musimin Herlan (Gatra, 08/ III, 11 Januari 1997) this sector has grown rapidly, in 1989 the home industry sector Tasikmalaya was only 5,695 units with 99,000 workers, and production volume was almost 174 billion. In 1995, that number increased to 7,906 units of home industry, 114,000 workers, and production volume reached 343 billion. Compared to 1993 , this home industry had increased to $16 \%$ in 1995. The improvement of Tasikmalaya's economy could also be seen by the increase of financial institutions. Currently no less than 61 agencies in Tasikmalaya were dealing with the credit which include 18 commercial bank branches, 4 branch offices of banks, 23 rural banks, 7 bank market, 6 rural banks (BPR - Bank Perkreditan Rakyat), and 3 other credit institutions .

The improving economic growth from year to year resulted in social problems for Tasikmalaya people which most of the engaged in the informal sector. Most people considered the patience of Tasikmalaya people like the patience of a master craftsman who forges iron to obtain the best results for a dagger. This is quite true, if it refers to the trading system, most Tasikmalaya people prefer to do the credit system. Tasikmalaya are known as mortgagee. This kind of trading system formed a social relationship among people because the seller and the buyer met each other more often (Mind, 12.30.1996). The presence of modern financial institutions had an impact on the typical business of Tasikmalaya people.

\section{Chronologies}

Thursday, December 19, 1996, security forces of the pesantren, the islamic boarding school, investigated the report of a resident students who were often lost money in the student dormitory students. The investigation resulted in a suspect that was a student named Muhammad Rizal (14 years), the son of a police officer of Tasikmalaya. Boarding party punished Rizal by soaking him in the pool. Rizal's parents did not agree with the detention, the schools security chief summoned to the police station, even though the problem was resolved amicably.

Monday, December 23, 1996, the Police, spokesperson arriving at the pesantren, ajeungan Ate Musadiq immediately conveyed the rules applied in boarding school for any violations made by students. However, while he was explained a few points, a police officer named Nursamsi suddenly hit him from behind. The beating shocked Ustadz Farid Mahmud, who was in reflect protecting his student. However, protective measures were interpreted by 
the other members of the police as a form of resistance to the police, the incident occurred in the examination room. Without any process they were put into a jail, together with any other prisoners. On the way to the jail they were out of control and make fun to the police officers. Not satisfied, the police beat Ihsan, who could do nothing but surrender. It was estimated there were nine policemen who participated in the persecution.

More torture happened when the three of them moved into a seperated cell room. Based on the Ustadz Farid Mahmud confession, in the cell room they were told to do the push-up as many as 60 times, squat-jump, and walk bent, and was burnt by cigarette butts, and even told to take off their shirts. They were kicked and punched during in the cell. At that time, they also received allegations as the follower of the "right" movement to the subversion. In the afternoon after they were home, Ustadz Farid Mahmud condition was getting worse, and immediately taken in to the hospital.

Ustadz Farid Mahmud was not hospitalized for long, because he was visited by a lot of people so as distinguished people for the sake of the other patients he was allowed to go home. After Ustadz Farid Mahmud returned from the hospital the issues of the Ustadz Farid Mahmud and KH Ma'mun death was spread widely in the society. Therefore, there was invitation to the public to have a pray in Masjid Agung on Thursday, December 26, 1996. After conducting a mass pray, they demanded the police officers who committed abuses against Ustadz Farid Mahmud and both student to be severely punished. On that occasion the police chief of Tasikmalaya, Letkol Suherman, apologized for the incident. However, they did not accept the police chief's sympathy, the people were already upset with the police.

The mass left the mosque to the Police Headquarters which is only about 100 meters away Masjid Agung. The mass' anger increased, arriving in front of the Police Headquarters Tasikmalaya, among the crowd it was heard shouts of "Allah Akbar", in the end, the Police Headquarters was subjected to the mass riot. At the same some mass were also vandalized the traffic signs around Mesjid Agung. Entering the time for dhuhur pray most people were back to the mosque, but some others were spread out into the street and continue their vadalism to HZ Mustafa street, throwing and damaging stores owned by the Chinese such as the shop of Logo, Jayakarta, and even Yogya Dept. Store and Matahari Department. Store. PT Dahana Berlian Motor was burned. Mass was not only targetting stored, but also the churches. Pantekosta churches were burned, GKI church was damaged, GKI Church in Jalan Veteran was burned, Bethel Church on Jalan Tentara Pelajar, Gereja Hati Kudus on Jalan Sutisna Senjaya were also damaged. Cars and motorcycles were found burnt along the way. (AP, 1/7/1997; Reflection Events Tasikmalaya, 1997: 9-20; Reuters, 30/12/1996). The Loss of the riot on December 26 was estimated at 85 billion.

\section{The riot cause analysis}

One of the assumption of 1996 Tasikmalaya riot was the persecution of UstadzFaridMahmudand both hisstudents by the police in Tasikmalaya Mapolres on Monday, December 23, 1996. But in fact, this assumption was not as simple as that. In the case of 1996 Tasikmalaya riots is necessary to distinguish between the use of the term "cause factor" and the "trigger". 
Understanding the causes of the riots and took notice of an event that occurred more comprehensively and, while understanding the trigger, just look at the facts or events that occurred prior to or simultaneously with the riots in Tasikmalaya in 1996. Therefore, the 1996 Tasikmalaya 1996 riots could not be separately understood, that is in isolation with social dynamics, economics, and politics both locally, and nationally. It required historical review to get a full understanding of the dynamics.

From the point of view of the mass psychology, the riots in 1996 is a form of collectivism (togetherness), the behavior performed jointly by a mob. Togetherness phenomenon is referred to as the collective behavior. One of the main forms of collective behavior can be either social movement or social action. Social movement is a collectivity that performs certain activities with sustainability levels to support or reject the changes occured in the community or group that includes collectivity itself (Turner and Killan in Arismunandar, 2007). Social movements are also interpreted as a large number of people who act together towards a number of goals or ideas. Typically, this movement involves ways that are not institutionalized, such as marches, demonstrations, protests, which support or oppose a social change. Therefore, social movement organized an action group for social change within groups, institutions, and society. Meanwhile, the collective behavior can occur spontaneously, or an action that is not organized (Suryanto, 2008).

The connection between the issues and rumors of violence in society often involves the established political structure, this political structure sometimes plays a significant role. In the history of Tasikmalaya, never had any conflict in the background of SARA (Etnic, Religion, Race, and Inter-group) happened and was really serious and threaten the integrity of the community. Never had also happened a conflict that break the religious hostility with the government, except during the colonial era (Mind, 30.12.1996). Although Tasikmalaya people is known for their mannered and tolerant, but that does not mean there is no conflict. There were several incidents happened in Tasikmalaya, though it does not cause riots. The incident related to the life of a small community. The following are data that can be collected regarding to the incidents:

1. Flour mills employee persecution. In 1970s there was a fuss in Tasikmalaya about a Chinese tapioca business owner that was rumored to have been tortured to death for doing wrong, by whipping with a whip made from stingray tail. But the incident did not inspire the spirit of anti-ethnic riots toward a certain ethnic (Mind, 30.12.1996).

2. Environmental pollution by Palem Soap Factory. The waste of the factory located in SL. Tobing street, Tasikmalaya, wastes polluted the environment around the plant. The local communities had protested the pollution several times. But it was ignored and the pollution continueed. The Tasikmalaya goverment had not been assertive toward this problem. The local goverment seemed to side the factory and it caused the distrust of people toward the apparatus (Gatra, 08/III/11/01/1997)

3. The case of the seizure of Hotel Priangan. The cases involving indigenous and nonindigenous entrepreneurs even had to be 
solvedoncourt, withajudge'sdecisionthat won the non-indigenous entrepreneurs. The santri (Islamic student) and the youth was quite tolerant responding this case. Each time the case was on court, hundreds of students and youths held demonstrations (KH. Endang Rahmat interviewed on 07/05/2009). The story begins with the dispute of Hotel Priangan and its auction that made bankrup the owner, Haji Nunung. The formal legal affairs were completed in 1988, with the defeating of $\mathrm{H}$. Nunung. The hotel was auctioned off, but the issue was that the auction was not fair, so $\mathrm{H}$. Nunung harmed (Rusmayadi, SH, interviewed on 11/05/2009). At the same time there was also about Ajengan Endik's defeat in court, in the case of debt with the same person. Therefore, allegations of collusion came in the court.However, the allegations of collusion were denied by Chairman of Tasikmalaya District Court, Karseno Atmotoyoso. "We judge based on the evidence. If the evidence is strong, yes we will make that party win the court, native or not. Debt that must be paid," he said responding to the collusion allegations in the case of $\mathrm{H}$. Nunung and Ajengan Endik (Gatra, 08/III, January 11, 1997)

4. The case of the old market relocation to Cikurubuk. The economic inequality and collusion is coloring the conversation of Tasikmalaya people after the case. Behind the relocation of Cihideung Market that was burned in 1992, the market was originally planned to be moved to Cilembang. But eventually it was relocated to Cikurubuk, far from human traffic, in the suburbs area of Tasikmalaya (Farid Mahmud KH, interviewed on
04/05/2009). The merchants were complaining. "It would be far from developing a business, and for being able to pay for the installments," said Otong Sumarna (54 years), a seller in Cikurubuk Market. According to information, the market should be moved to Cikurubuk because there is a strong businessman who had targeted the location of Cilembang. Cihideung area will be develop as an elite shopping center, therefore the grocery stores, and other "second class" goods in Pasar Wetan and Pasar Kidul that had been there for decades behind the Cihideung trade center must be relocated to the location at Pasar Cikurubuk, Desa Linggajaya, $2 \mathrm{~km}$ to the south from the former location, event though this relocation was portested and worried most of the sellers (Mahmudin, 43 years old, interviewd on 14/05/2009). Most sellers in those markets were native and did not have much capital, they were put away out of the town. While in the former market location a modern supermarket was built. The sellers had delivered their complains to DPRD Jabar, yet the decision was they still have to go from the former location (Pikiran Rakyat, 29/12/1996).

The mass mobilization with the purpose of holding prayers at Masjid Agung of Tasikmalaya is a manifestation of solidarity against the mistreatment of Ustadz Farid Mahmud and the two students. Islamic culture in Tasikmalaya has put to a strong social structure, as what Jackson (1990: 200) called, dyadic relationships, or the patron-client relationship of Scott. The strong influence of Islam in Tasikmalaya society put kayi in the stratification position of respectable society. The social relations 
between kyai and their students, and among the common people is reinforced by intelectual relationship.

The pesantren intellectual relationship can be described as a cell tissue, the main pesantren as the center developed branches continously. This intelectual relationship is such as tarekat (order) (Dhofier, 1994: 8590). Eventhough does not developed such tarekat like any other pesantren, Pesantren Condong is the salafiah pesantren which has the almuni network all over Tasikmalaya and the sorrounding area, the social and intellectual relation is really well maintained. The solidarity of santri and Moslems movement in Tasikmalaya that result in a riot in 1996 was using such intelectual and social network, and the social structure of Tasikmalaya people, that could create an ideology movememnt.

The collective awareness developed in a religious base could be the background to explain the riot in Tasikmalaya in 1996 which was spread rapidly in the name of religion. Tasikmalaya is the base of Moslem in West Java, and has a strong pesantren tradition. According to Dhofier (1994) pesantren has the main devices to develop the solidarity, which are able to develop the pesantren tradition, through:

1. the closest family that would be the next leader of that pesantren.

2. the endogamous married network among the kyai family.

3. developing a tradition of knowledge transmission and intellectual transmission chain among kyai and their family (Dhofier, 1994: 61-62).

The factor determined a historical event such as the riot in Tasikmalaya in 1996 has a casuality (reason-effect) relationship. Therefore, it can be said that the riot in
Tasikmalaya had happened in the society powered "the collective awareness". Like insomnia, it was born as the result of the "unresolved" problem that keep piling up inside someone's head. Smelser (1962), in the Theory of Collective Behavior describe ssix requirements of the pre-condition of collective behaviour.

Furthermore, Smelser identifies six steps that a condition can result into a collective behaviour (Mustain, 2007: 187188; Suryanto, 2008), which include: (a) structural conduciveness, some social structure that might emerge the collective behavior such as: market, public places, worship places, mall, and others; (b) structural strain, the emerging of intensity in the society structuraly, such as the care of the flour mill, the pollution case, and Priangan hotel case. (c) generalized beliefs: share interpretation of event, the prejudice development toward something, such as the goverment, a certain race, religion, or politic opponent; (d) precipitating factors: the triggering incidence, the troture of Ustadz Mahmud Farid; (e) mobilization for actions: the mass mobilization; dan (f) failure of social control - as the result that the agent whose task is to do the social control does not do the job well.

Pruitt \& Rubin (2004: 4-6) describe five basics of approaching conflict, which include contending, yielding, problem solving, withdrawing, and inaction. Contending tried to implementing a solution prefered by one of the parties. This strategy considered one party is higher than the other. The yielding strategy is to decrease our own aspiration and willing to accept less than expected, thus there is a bigger consideration towards others. The problem sloving is to find out alternatives that can satisfy both parties. The fourth is 
withdrawing, which is to leave the conflict situation, physically and psycologically. This strategy proves that the parties in conflict have a low consideration toward themselves and the other parties. The fifth strategy is inaction, do nothing, the parties in conflict are waiting the next step from the other party, in an uncertain time.

There are several strategies of conflict resolution, including negotiation, mediation, and arbitration of adjudication (Maftuh, 2008: 48). These strategies are the non-violent strategies. Negotiation, both parties solved the conflict together, achieving mutual settlement without involving the third party. Both parties are not finding the solution in accordance with the apllied rules, but they are creating rules for themselves. These include the collaborative problem solving and negotiation.

Mediation involves a third party to intervene in a dispute to help the parties in dispute to reach an agreement. Mediator maybeappointed bytheparties in dispute or representing an authority other the parties in dispute. The parties in dispute must agree with the mediator intervention.

Arbitration is where both parties in dispute agree to third-party intervention and both parties in dispute had to agree in advance that they will accept any decision from the third party. Adjudication, if there is intervention from a third party that has the authority to intervene in the dispute and make and implement the decision, either expected or not by both parties to the dispute. The court system is the best example of adjudication. Strategies or processes used in conflict resolution are an attempt being made to resolve the conflict through the non-violent means.
A number of potential local values (framing processes) in a transitional situation can be used by a figure to mobilize the masses. This process uses institutions, organizations, and local associations to mobilize. However, this mobilization efforts need to consider the presence or absence of opportunity and threat. Therefore, Moore Jr (1977 in Mustain, 2008: 29) explains that although farmers in the agricultural society are just bunch of common people, but they can be a great power, because they are coordinated and obey their village leader and elites.

\section{Conclusion}

Riots and social movements in the history point of view are the behavior of community members that arise spontaneously, but the problem roots can be traced from the accumulation of events that lead to disappointment and frustration of the public. Such measures in the sociology are categorized as the collective behavior. Collective behavior can be interpreted as the act of relatively spontaneous, unstructured and unstable from a group of people, which aims to eliminate the sense of dissatisfaction and anxiety. A collective behavior will not merely show up without trigger. Collective behavior is seen as an attempt to change the social environment. The efforts are based on a generalized belief that can be interpreted as something that is a common belief.

The collective behavior, in this respect, resembles the concept of value added, where there are several steps that must be done to transform raw materials into a finished goods. Each step will add the value of the product that will be produced and each step will be combined with the previous step before the next step can be implemented. 
SRIYANTO,

The Tasikmalaya Chaos in 1996: Between the Society's Solidarity and the Socio-Economy Imbalance

The theoretical base used in this study is intended to explain what events led to the emergence of collective behavior and predict the result the collective behavior

\section{REFERENCES}

Berg, B.L. (2007). Qualitative Research Methods for the Social Sciences, 6th. Edition. Boston: Parson Education Inc.

Bogdan, R.C., \& Biklen, S.K. (1990). Qualitative Research for Education, An Introduction to Theory and Methods. Jakarta: PAU-PPAI Universitas Terbuka.

Burke, P. (2003). Sejarah dan Teori Sosial. Jakarta: Yayasan Obor Indonesia.

Dhofier, Z. (1994). Tradisi Pesantren, Studi Tentang Pandangan Hidup Kyai. Jakarta: LP3ES.

Ekadjati, E.S. (1995). Kebudayaan Sunda (Suatu Pendekatan Sejarah). Jakarta: Pustaka Jaya.

Iskandar, M.(2001).Pergulatan Pemikiran Kiai dan Ulama di Jawa Barat 19001950, Para Pengemban Amanah. Yogyakarta: Mata Bangsa.

Jackson, K.D. (1990). Kewibawaan Tradisional, Islam, dan Pemberontakan: Kasus Darul Islam di Jawa Barat. Jakarta: Pustaka Utama Grafiti.

Maftuh, B. (2008). Pendidikan Resolusi Konflik, Membangun Generasi Muda yang Mampu Menyelesaikan Konflik Secara Damai. Bandung: Prodi PKn \& Sekolah Pascasarjana UPI.

Miles, M.B., \& Huberman, A.M. (1992). Analisis Data Kualitatif. Translate by Tjetjep Rohendi Rohidi. Jakarta: UI Press.

Moleong, L.J. (2007). Metodologi Penelitian Kualitatif. Bandung: Remaja Rosdakarya.
Mustain. (2007). Petani vs Negara. Gerakan Sosial Petani Melawan Hegemoni Negara. Jogjakarta: ArRuzz Media.

Pruitt, D.G. \& Rubin, J.Z. (2004). Teori Konflik Sosial (terjemahan). Yogyakarta: Pustaka Pelajar.

Scott, J.C. (1993). Perlawanan Kaum Tani. Jakarta: Yayasan Obor Indonesia.

Sholeh, B., dan kawan-kawan, (tt.). Agama, Etnisitas Dan Radikalisme: Pluralitas Masyarakat Kota Sala. Laporan Penelitian UIN Syarif Hidayatullah Jakarta.

Sjamsuddin, H. (2002). "Rusuh Di Bandung: Peristiwa 5 Agustus 1973 Dalam Liputan Media Massa”, in HISTORIA. Jurnal Pendidikan Sejarah No. 6, Vol. III Desember 2002.

Skocpol, T. (1991). Negara dan Revolusi Sosial, Suatu Analisis Komparatif tentang Perancis, Rusia, dan Cina (translate Kelompok MITOS). Jakarta: ERLANGGA.

Smelser, N.J., (1962). Theory of Collective Behavior. New York: The Free Press,

Media Transparansi. Edisi 9/Jun 1999. "Pemilu 1997, Contoh Terakhir Pemilu Setengah Hati”.

Gatra, Edisi 001/III, 11/07/1997.

Harian Terbit, Edisi 27/12/1996; 28/12/1996; 29/12/1996; 02/01/1997; 03/01/1997.

Pikiran Rakyat, Edisi 27/12/1996; 28/12/1996; 29/12/1996; 30/12/1996; 18/02/1997; 20/02/1997; 25/02/1997; 26/02/1997.

TEMPO Interaktif, 07/01/1997.

Interview:

KH. Drs. Mahmud Farid, 04/05/2009.

KH. Drs. Endang Rahmat, 07/05/2009. Abay Bayanudin (40 tahun), 06/05/2009. 